\title{
The structure and diversity of freshwater diatom assemblages from Franz Josef Land Archipelago: a northern outpost for freshwater diatoms
}

Sergi Pla-Rabés, Paul B Hamilton, Enric Ballesteros, Maria Gavrilo, Alan M. Friedlander, Enric Sala

We examined diatom assemblages from 18 stream and pond samples in the Franz Josef Land Archipelago (FJL), the most northern land of Eurasia. More than 216 taxa were observed, revealing a rich circumpolar diatom flora, including many undescribed taxa. Widely distributed taxa were the most abundant by cell densities, while circumpolar taxa were the most species rich. Stream and pond habitats hosted different assemblages, and varied along a $\mathrm{pH}$ gradient. Diatoma tenuis was the most abundant and ubiquitous taxon. However, several circumpolar taxa such as Chamaepinnularia gandrupii, Cymbella botellus, Psammothidium sp. and Humidophila laevissima were also found in relatively high abundances. Aerophilic taxa were an important component of FJL diatom assemblages (Humidophila spp., Caloneis spp. and Pinnularia spp.), reflecting the large and extreme seasonal changes in Arctic conditions. We predict a decrease in the abundance of circumpolar taxa, an increase in local ( $\alpha-)$ freshwater diatom diversity, but a decrease in regional diversity (circumpolar homogenization) as a result of current warming trends and to a lesser extent the increasing human footprint in the region. 
1 The structure and diversity of freshwater diatom assemblages from Franz Josef Land

\title{
2 Archipelago: a northern outpost for freshwater diatoms
}

3 Sergi Pla-Rabès ${ }^{1}$, Paul B. Hamilton ${ }^{2}$, Enric Ballesteros ${ }^{3}$, Maria Gavrilo ${ }^{4}$, Alan M. Friedlander ${ }^{5,6}$ and Enric 4 Sala $^{6}$

5

6

7

8

9

10

11

12

Corresponding Author:

20

Sergi Pla-Rabés

21

\author{
${ }^{1}$ Centre for Ecological Research and Forestry Applications (CREAF), Campus UAB, Edifici C, 08193 \\ Cerdanyola del Vallès, Barcelona, Spain \\ ${ }^{2}$ Canadian Museum of Nature, Research and Collections, P.O. Box 3443, Station D, Ottawa, K1P 6P4, \\ Canada \\ ${ }^{3}$ Centre d'Estudis Avançats de Blanes-CSIC, Acc. Cala Sant Francesc 14, 17300 Blanes, Girona, Spain. \\ ${ }^{4}$ National Park Russian Arctic, Sovetskikh kosmonavtov pr., 57, Archangelsk, 163000, Russia \\ ${ }^{5}$ Fisheries Ecology Research Laboratory, University of Hawaii, Honolulu, Hawaii, USA \\ ${ }^{6}$ National Geographic Society, Washington, DC, USA
}

1 Campus UAB, Edifici C, 08193 Cerdanyola del Vallès, Barcelona, Spain

Email address: sergiplarabes@gmail.com 
24 Abstract

25

26 We examined diatom assemblages from 18 stream and pond samples in the Franz Josef Land

27 Archipelago (FJL), the most northern land of Eurasia. More than 216 taxa were observed,

28 revealing a rich circumpolar diatom flora, including many undescribed taxa. Widely distributed

29 taxa were the most abundant by cell densities, while circumpolar taxa were the most species rich.

30 Stream and pond habitats hosted different assemblages, and varied along a $\mathrm{pH}$ gradient. Diatoma

31 tenuis was the most abundant and ubiquitous taxon. However, several circumpolar taxa such as

32 Chamaepinnularia gandrupii, Cymbella botellus, Psammothidium sp. and Humidophila

33 laevissima were also found in relatively high abundances. Aerophilic taxa were an important

34 component of FJL diatom assemblages (Humidophila spp., Caloneis spp. and Pinnularia spp.),

35 reflecting the large and extreme seasonal changes in Arctic conditions. We predict a decrease in

36 the abundance of circumpolar taxa, an increase in local ( $\alpha-)$ freshwater diatom diversity, but a

37 decrease in regional diversity (circumpolar homogenization) as a result of current warming

38 trends and to a lesser extent the increasing human footprint in the region. 


\section{Introduction}

The Arctic is warming faster than any other region on the globe, which imposes new challenges to the resilience of this region and its diversity. Freshwater ecosystems are particularly sensitive to global and local stressors such as climate change, atmospheric pollution, alien species introductions, and resource development, which can all alter biogeochemical cycles. Much of the Arctic is still poorly explored, hence little is known about the impact of climate change on northern freshwater and marine ecosystems (e.g. Chernova et al. 2014). There is on-going international interest in expanding monitoring programs on climate change, particularly in the polar regions (UNESCO 2009; AMAP 2015). This will become increasingly more important as resource development and tourism in the Arctic is expected to increase dramatically in the coming decades.

Arctic ponds and lakes can be considered as sentinels of the changing Arctic (Williamson et al. 2008). Their freshwater living biota, mainly diatoms (Bacillariophyceae) and cyanobacteria, are the most abundant and diverse photosynthetic groups found in these habitats. Paleolimnological studies using freshwater diatoms across the Arctic have documented past climatic changes (e.g. Smol et al. 2005). The most striking change, which is still on-going, has been the expansive increase in diatom productivity and diversity since the 1950s (Gajewski et al. 1997). Despite these rapid changes, we have a limited understanding of the stability (i.e. fluctuations in the occurrence and abundance of species through time) of these freshwaters systems. In addition to changing climate, the expanding human footprint in the Arctic has resulted in increased contamination by heavy metals such as mercury and arsenic (Chetelat et al. 2014). Questions 
61 about biological stability, including native species loss and introduction of invasive species have 62 yet to be addressed.

63 The Franz Josef Land (FJL) Archipelago is the most northerly land in the Arctic region of

64 Eurasia. All islands in the archipelago belong to the specially protected area of Franz Josef Land 65 state federal wildlife refuge (corresponding IUCN category IV) and are managed by the Russian 66 Arctic National Park. High Arctic exploration, mining, fishing, and tourism, particularly to the 67 remote northern islands, has always been limited due to logistical constraints. Consequently, 68 little is known about the ecology and distribution of the FJL freshwater diatom flora.

69 Nevertheless, at the end of the 19th century, the Austro-Hungarian Tegetthoff expedition (1872-

70 1874), sampled marine bottom sediments and Grunow (1884) noted several diatom species in his 71 monograph, but only a few freshwater diatoms were reported. Later in that century the Jackson72 Harmsworth Expedition to FJL (1894-97) collected about 20 samples, mainly from Cape Flora, 73 but also from Cape Neal and Bell Island, including a mud sample from an off-shore drifting ice74 floe (Cleve 1898). A total of 101 diatom morphotypes were observed, including 27 freshwater 75 taxa identified in the ice-floe sample. During the first half of 20th century, Peter Shirshov (1935) 76 sampled four lakes in FJL and compared their algal flora with lakes at Novaya Zemlya, a large 77 Russian island $\sim 500 \mathrm{~km}$ to the southeast of FJL. Diatom floras from the high Arctic (FJL, 78 Spitsbergen, Beeren Island, Jan Mayen and East and West Greenland) differed from floras in the 79 lower Arctic region (e.g. Siberia and Lapland) (Cleve, 1898).

80 Since the 1950s numerous surveys have increased our knowledge on the rich Arctic diatom flora 81 (Foged 1953; Foged 1955; Foged 1958; Foged 1964; Foged 1973; Foged 1974; Foged 1977;

82 Foged 1981; Lange-Bertalot \& Metzeltin 1996; Metzeltin \& Witkowski 1996; Lange-Bertalot \& 
83 Genkal 1999; Antoniades et al. 2008), but there is only one recent study on diatoms from FJL 84 (Zauer 1963).

85 New species are frequently described as locally endemic (i.e. Van De Vijver et al. 2004), but are 86 quite often later reported from other Arctic localities. Hence, several studies support the idea of a 87 circumpolar diatom distribution (Lange-Bertalot \& Metzeltin 1996; Metzeltin \& Witkowski 88 89

\section{6; Lange-Bertalot \& Genkal 1999; Antoniades et al. 2008). Drifting icebergs and ice-floes} may act as vectors in the circumpolar distribution of microorganisms (Cleve 1898). In addition, the ability of some diatoms to survive aerial voyages by wind and bird transportation are also possible dispersal mechanisms (Kristiansen 1996). Consequently, there is a need to explore more Arctic sites to understand the biogeography of circumpolar microorganisms.

The objective of this research is to document parts of the diatom flora of FJL, a poorly studied region in the high Arctic in order to establish a baseline for future studies. We also examine biogeographical connections with Greenland, Siberia, Spitsbergen, and northern Canada. Finally, we propose a hypothesis driven theoretical framework on the effects of recent and past climate warming scenarios on species richness for future studies and investigate future scenarios for conservation of circumpolar biodiversity.

\section{Methods}

\section{Study area and sites}

FJL is a large archipelago that occupies an area of $16,000 \mathrm{~km}^{2}$ and consists of 192 islands. The archipelago was formed together with the Spitsbergen Archipelago by the uplift and broken margin of the Barents Shelf (Solheim et al. 1998). FJL is basically a remnant of the basaltic 
105 plateau fractured by tectonic faults and covered by glaciers (over $85 \%$ ), with the highest

106 elevation at ca. $600 \mathrm{~m}$. Most of the islands are small, only nine exceed $500 \mathrm{~km}^{2}$ with large ice-

107 free areas of $80-500 \mathrm{~km}^{2}$ on only four islands.

108 FJL lies within the high arctic climatic zone, with an average annual air temperature of $-13.2^{\circ} \mathrm{C}$.

109 July and August are the only two months with average air temperatures above zero $\left(+0.7^{\circ} \mathrm{C}\right.$ and

$110+0.1^{\circ} \mathrm{C}$, respectively) (VNIIGMI-MCD data accessed at http://oopt.aari.ru). Periods with above

111 freezing average daily temperatures last from 2 months in the southern portion of FJL to 1.5

112 months in the north. Rainfall averages $250-300 \mathrm{~mm}^{-}$year ${ }^{-1}$ with only $40 \mathrm{~mm}$ during warm

113 months. On average, FJL is much colder than Spitsbergen, which has an annual air temperature -

$1147^{\circ} \mathrm{C}$, and four months with air temperatures above zero (Førland et al. 2011), warmer than the

115 Canadian high Arctic islands (e.g. average annual air temperature in Eureka, Nunavut $-19.9{ }^{\circ} \mathrm{C}$,

116 additional data can be found in http://www.eureka-nt.climatemps.com/temperatures.php).

117 The hydrographical network of FJL is not well developed; most of the streams are temporal,

118 while all rivers are completely frozen in winter. There are over 850 lakes and ponds in FJL but

119 only 10 of them are deeper than $1 \mathrm{~m}$ (i.e. not frozen to the bottom M. Gavrilo field observation).

120 Principal water sources are melting snow and glaciers. Thus, most of freshwater habitats are very

121 harsh, having short growing season and are only temporary.

122 Approval to conduct field studies was granted by the Russian Federation Ministry of Education

123 and Science Approval Ref. No. 14-368 of 06.05.2013 permission to the Russian Arctic National

124 Park.

\section{Diatoms analysis}


126 During the 2013 National Geographic Pristine Seas expedition to FJL, 18 samples from

127 freshwater habitats (2 lakes, 7 ponds, and 9 streams) were sampled from different islands across

128 the archipelago (Fig. 1, Table 1). Scrapings were done on rock surfaces, which consisted of a

129 mixture of mosses and cyanobacteria biofilm. In the field, samples were fixed and preserved in $1303 \%$ formaldehyde.

131 Diatom samples were processed by hot digestion using hydrogen peroxide $\left(33 \% \mathrm{H}_{2} \mathrm{O}_{2}\right)$ and $\mathrm{HCL}$

132 (2 $\mathrm{ml} 1 \mathrm{M})$. Through a series of dilutions, the peroxide and acid were removed. Subsequently, the 133 samples were dried onto cover glass and mounted in $\operatorname{Naphrax}^{\circledR}$ (R.I.=1.7, Brunel Microscopes

134 Ltd., UK) on a microscope slide following the method described in Battarbee et al. (2001). Five 135 hundred diatom valves per slide sample were identified and counted across random transects at 136 1,000x magnification using a Zeiss Axio Imager A1 microscope (Carl Zeiss Inc., Germany) 137 equipped with a 100x objective (Zeiss Plan-Apo 1.4 numeric aperture) and differential 138 Interference contrast optics. Scanning electron micrographs were taken using a FEI Quanta 139 2000-F-SEM (10 kV, WD $10 \mathrm{~mm})$.

140

141 Diatom identifications were based on contributions by Lange-Bertalot \& Metzeltin (1996);

142 Metzeltin \& Witkowski (1996); Lange-Bertalot \& Genkal (1999); Krammer (2000); Lange-

143 Bertalot (2001b); Lange-Bertalot (2001a); Krammer (2002); Krammer (2003); Van De Vijver et

144 al. (2004); Antoniades et al. (2008); Kulikovskiy et al. (2010); Zimmermann et al. (2010);

145 Lange-Bertalot et al. (2011); Levkov (2013).

\section{Data analysis}


147 Detrended correspondence analysis (DCA) was conducted to estimate the length of the gradient 148 on the square-root-transformed diatoms abundance data. Due to the large length of the gradient

149 (> 5 SD), a Principal Coordinates Analysis (PCO) was used based on Hellinger distances to 150 reveal the structure among the sampled diatom assemblages (Legendre \& Legendre 1998). Only

151 diatoms with abundances $>1 \%$ in at least one sample were included in the PCO, which was 152 performed using CANOCO 5.0 (ter Braak \& Šmilauer 2012).

153 Diatom assemblage diversity was calculated in terms of species richness (S) and the exponential 154 of Shannon's entropy $[\exp (\mathrm{H})]$, which is more appropriate than classical diversity indices for 155 assessing statistically independent measures of alpha ( $\alpha)$ and beta ( $\beta$ ) diversity (Jost 2007). For 156 each habitat type (lentic and lotic), diversity (D) was partitioned into $\alpha, \beta$, and gamma ( $\gamma$; total 157 diversity) components following Jost (2007). Beta diversity was used as a measure of the 158 differences in the species composition between habitat types. Evenness was calculated using two 159 diversity orders. The first, of order 1 , is based on Shannon entropy $\left(\mathrm{EF}_{1}\right)$ and the second, of order $1602\left(\mathrm{EF}_{2}\right)$ is based on Simpson's diversity metric (Jost 2010). Hence, $\mathrm{EF}_{2}$ is an approach to the 161 proportion of the dominant species in the assemblage, whereas $\mathrm{EF}_{1}$ also takes into account all the 162 common species in the assemblage.

163 In order to recognize a discontinuous subset of samples, a K-means clustering with the optimal 164 number of groups chosen according to the Calinski-Harabasz pseudo-F-statistic was performed 165 (Legendre \& Legendre 1998). The ecological indicator values for each diatom taxon were 166 identified to assess the ecological preferences of individual species for each of the clusters. The 167 Indval-index was employed to control the effects of unequal size of groups (De Cáceres \& 168 Legendre 2009). 
169 All analyses of diversity metrics were performed using the R statistical program (R v. 3.0.2.;

170 http://www.r-project.org/) and additional functions from the R-packages "vegetarian" v. 1.2 ,

171 "vegan"v. 2.2-1 and "indicspecies" v. 1.7.4 to calculate Indval-index.

172

173 Results

174 A total of 216 benthic diatom taxa belonging to 44 genera were identified from the 18 samples

175 from FJL. Seventy-two taxa occurred only in lentic (ponds/lakes) environments, 42 occurred

176 only in lotic (streams) environments, while the remaining taxa were found in both habitats. The

177 checklist of all taxa with their means, highest abundances, and biogeographic distributions

178 (circumpolar versus widely distributed) are found in Appendix 1. Widely distributed species, or

179 those with broader distribution than circumpolar, dominated the samples by cell numbers, but

180 more circumpolar taxa dominated species richness (Appendix 1). In lotic ecosystems, the

181 following widely distributed taxa were dominant: Diatoma problematica, Fragilaria capucina

182 (complex), Rossithidium petersenii, Diatoma tenuis, Eucocconeis laevis, Psammothidium

183 marginulatum, Nitzschia homburgensis, Meridion circulare, Achnanthidum minutissimum sensu

184 lato, Psammothidium kryophilum and Hannaea arcus. Taxa such as $P$. marginulatum and $A$.

185 minutissimum sl. are composed of a mix of widely distributed and circumpolar taxa. Four other

186 circumpolar taxa had abundances $>9 \%$ : Encyonema fogedii (complex), Cymbella botellus,

187 Psammothidium sp1, and Cymbella cleve-eulerae. Several widely distributed taxa showed high

188 abundances in lentic environments, including: Nitzschia alpina, Tabellaria flocculosa,

189 Encyonema silesiacum, Naviculadicta digitulus, and Humidophila gallica. In contrast,

190 circumpolar taxa such as Chamaepinnularia gandrupii, Fragilaria cf. perminuta, Nitzschia cf.

191 sublinearis, and Hippodonta arctica had lower abundances in lentic habitats (Fig. 2). Two 
192 widely distributed taxa showed similar patterns of dominance in both lotic and lentic habitats:

193 Diatoma tenuis and Hygropetra balfouriana. A number of taxonomically unidentified forms

194 were also observed (Appendix 1).

195 Ponds supported 82 circumpolar taxa and streams 62. Mean taxa richness per sample was $41( \pm$

$19612 \mathrm{sd})$ for ponds and 33 ( $\pm 16 \mathrm{sd})$ for streams, although this difference was not significant (t-

197 test $=1.20, \mathrm{p}>0.05$ ). A similar pattern was observed for diversity metrics (Fig. 3 ). $\beta$-diversity

198 showed large differences between stream and pond habitats $\left(\beta\right.$-diversity of order $1 ; \mathrm{H}_{\beta}{ }^{1}=3.4$ for

199 streams and $\mathrm{H}_{\beta}{ }^{1}=2.8$ for ponds). Stream samples showed higher variability compared to ponds

200 (Fig. 4).

201 One stream sample from Cape Flora was dominated by Diatoma problematica ( $80 \%$ of the

202 assemblage), and was removed for further analysis (FJ03, table 1, Fig. 2). K-means cluster and

203 PCO analysis showed five main assemblages (excluding FJ03 sample). The first PCO component

204 explained $18.9 \%$ of the variability, and showed some overlap between ponds/lake and stream

205 diatom assemblages. On the negative end of this first component, the species with higher

206 correlation were R. petersenii, P. marginulatum and Cymbopleura stauroneiformis (Fig. 4);

207 Caloneis holarctica, Nitzschia cf. sublinearis, and Stauroneis subgracilis were at the positive

208 end of Component 1 (Fig. 4). Additionally, stream diatom assemblages were separated in two

209 groups along the second PCO axis, which explained an additional13.6\% of diatom assemblage

210 variability (Fig. 4). Negative scores were mainly associated with northern sites (Nansen, Wilton,

211 and Kuhn islands), with Eunotia bilunaris, Neidium bisulcatum, Humidophila ingeiiformis, and

212 H. laevissima showing the highest correlation. On the positive end of PCO 2, the species with the

213 highest correlation were Amphora copulata, E. fogedii (complex), Psammothidium bioretii,

214 Encyonema cf. spitsbergense, and E. laevis (Figs 2, 4). The third PCO axis explained an 
215 additional $10.1 \%$ of variability, which separated lake samples (cluster 4 ) from the other habitats.

216 Widely distributed species such as Encyonema reichardtii, E. silesiacum, Staurosirella pinnata,

217 Nitzschia alpina, and N. digituloides had the greatest influence in the lake cluster.

218 In order to further identify representative species for each cluster, species indicator values

219 (Indval) were applied. Cluster 4 (lakes) was characterised by more widely distributed species,

220 which were highly correlated with PCO axis 3. Cluster 2, which had the highest species richness

221 and diversity, was characterised by aerophilic Arctic species: Caloneis fusus, Humidophila

222 paracontenta, Caloneis fasciata, H. laevissima, and Luticola paleoarctica, as well as a high

223 abundance of C. gandrupii. In addition, Nitzschia homburgensis, which has a broad

224 biogeographic distribution (Fig. 2), was also found in cluster 2. Cluster 3 was characterized by

225 circumpolar species such as $C$. gandrupii, $C$. holartica, $N$. cf. sublinearis, Nitzschia sp.A, and

226 Sellaphora rectangularis sensu lato (Fig. 2). Cluster 5 consisted mainly of C. stauroneiformis,

227 Gomphonema nathortsii, Psammothidium sp1, and Eunotia scandiorussica. Cluster 1 consisted

228 of three cosmopolitan species, A. copulata, Encyonema laevis, and Nitzschia cf. acidoclinata,

229 along with one widely distributed species - E. fogedii (complex). In addition, some circumpolar

230 species such as Gomphonema lapponicum, Amphora dusenii, and Amphora spitzbergensis only

231 occurred in samples from this cluster (Fig. 2).

232 Although, diversity measures did not show significant differences between stream and ponds,

233 statistical differences were observed among clusters. Cluster 2 (Fig. 5) showed the highest

234 diversity and richness per sample. This group consisted of two stream samples (Kuhn and Wilton

235 islands) and three pond samples (Cape Tegetthoff, Cape Flora, and Tikhaya Bay). Measures of

236 equitability showed that higher richness was mainly due to the codominance of "satellite" 
237 species rather than the codominance of only dominant ones. This higher richness was significant

238 for $\mathrm{EF}_{1}$ but not for $\mathrm{EF}_{2}$ (Fig. 5).

239 Discussion

240 Diversity and distribution patterns

241 The reported number of diatom taxa per sample in our study was similar to previous Arctic

242 surveys (Douglas \& Smol 1995; Laing et al. 1999; Weckstrom \& Korhola 2001; Antoniades \&

243 Douglas 2002; Michelutti et al. 2003; Jones \& Birks 2004; Antoniades et al. 2005). However,

244 these surveys also sampled surface sediments, which could have increased the number of

245 observed taxa per sample. Surface sediment samples often integrate a disparity of habitats over

246 time. Our study also found many diatom morphotypes that could not be identified, illustrating

247 that taxa still need to be described, and supporting the recognition of high diversity and richness

248 of freshwater diatoms across the Arctic (Foged 1981; Antoniades et al. 2008; Pinseel et al.

249 submitted). Many species (new Arctic taxa) are presently included within species complexes

250 (e.g. A. minutissimum, N. cf. perminuta, E. cf. fogedii, P. marginulatum) or yet to be described

251 (e.g. Psammothidium sp1).

252 The large compositional turnover among samples (5.3 sd in the DCA) indicates large differences

253 in diatom assemblages among sites. The main source of diatom assemblage variability was

254 related to habitat (PCO axis 1; lotic versus lentic). Nevertheless, two clusters (2 and 5; Fig. 4)

255 had samples from both lotic and lentic habitats, similar to findings from Spitzbergen (Pinseel et

256 al. submitted). Small pond assemblages could be largely influenced by the arrival of taxa from

257 streams (Antoniades \& Douglas 2002), and conversely streams with low velocity (discharge)

258 could support lentic assemblages. Unfortunately, we do not have stream velocity or water

259 residence time data to confirm these observations. However, characteristic taxa of stream 
260 habitats in FJL, such as $R$. petersenii and F. capucina (complex), were also common in FJL pond 261 samples. This observation indicates that pond diatom assemblages in FJL may be influenced by

262 streams, as observed in other Arctic regions (Antoniades \& Douglas 2002; Pinseel et al.

263 submitted). Therefore, the dominance of stream taxa in pond sample FJ07 suggests a large

264 influence of stream species. The same reasoning can be applied to the pond samples in cluster 2

265 (FJ04, FJ06, and FJ15), but results are less evident. This cluster, showed higher richness and

266 diversity, with a dominance of circumneutral/slightly acidic taxa (pH optima ca. 6.8-7.2) such as

267 C. gandrupii, H. gallica, H. laevissima, P. marginulatum, N. homburgensis, and H. balfouriana

268 (Antoniades et al. 2004; Antoniades et al. 2008). On the PCO biplot, cluster 1 (Fig. 4, with only

269 stream samples), was characterised by the presence of alkaliphilic taxa [optimum $\mathrm{pH} 8.0-8.3$ in

270 Antoniades et al. (2008)] such as, E. laevis, P. bioretii, E. fogedii (complex), A. copulata, and $A$.

271 inariensis. Therefore, this second axis of diatom variability is likely correlated with a $\mathrm{pH}$

272 gradient, which is a main source of variability for diatom assemblages (Battarbee et al. 2001),

273 with Algers, Mabel, and Wilkzec islands potentially marking alkaline conditions with higher $\mathrm{pH}$.

274 The $\mathrm{pH}$ gradient should be, in part, related to the complex archipelago geology with intrusions of

275 basalt between sedimentary bedrocks (Dibner \& Fursenko 1998). However, recent deglaciated

276 areas tend to have increased alkalinity and $\mathrm{pH}$ in lakes and streams from bedrock and till

277 exposure (Engstrom et al. 2000; Milner et al. 2007). Thus, lake age (Milner et al. 2007) could be

278 an alternative hypothesis to explain the lower $\mathrm{pH}$ optima of the characteristic taxa from cluster 2,

279 rather than changes in the site geological settings.

280 Interestingly, the samples from cluster 2 also showed higher diversity metrics, due to the higher 281 equitability among the non-dominant taxa $\left(\mathrm{EF}_{1}\right)$. Less stable environments exposed to physical

282 stressors (e.g. current flow) could impact dominance by minimizing the effects of competitive 
283 exclusion and promoting species coexistence (Hughes et al. 2007) maintaining species diversity

284 (Chesson 2000). In Antarctic streams, environmental instability (changes in stream velocity and

285 successive periods of freezing and thawing) promote small cell size, maintaining higher diatom

286 richness (Pla-Rabes et al. 2013), with diatom assemblages showing higher resilience (recovery to

287 pre-disturbance conditions; e.g. flood event) (Stanish et al. 2011). There are indicators to suggest

288 that the biology at some FJL sites support high environmental variability. First, cluster 2 samples

289 are characterised by the presence of aerophilic taxa (H. laevissima, H. paracontenta, and C.

290 fusus), which indicate potential periods of lower water availability, and possibly even

291 desiccation. Second, species from cluster 2 showed lower $\mathrm{pH}$ optima (6.8-7.2 in Antoniades et

292 al. 2008) compared to cluster 1 (7.9-8.2 in Antoniades et al. 2008), which means lower buffering

293 capacity in cluster 2 sites, and consequently higher environmental variability. Furthermore, lower

294 alkalinity sites would tend to be older (Milner et al. 2007), and consequently have a higher

295 chance of accumulating species (Adler et al. 2005). Interestingly, cluster 2 sites showed large

296 expanses of ice-free areas (Khun and Wilton Islands), and more human influence (Tikhaya Bay,

297 Cape Tegetthoff, Cape Flora). Nevertheless, our data set did not include samples from the largest

298 ice-free areas located on the largest islands in the archipelago (Alexandre Land and Prince

299 George Land), which could potentially be diversity hotspots due to large biogeographic sizes.

300 Biogeographical patterns

301 The general diatom flora observed in FJL is similar to other circumpolar localities (Cleve 1898;

302 Lange-Bertalot \& Genkal 1999; Antoniades \& Douglas 2002; Stewart et al. 2005; Antoniades et

303 al. 2008). A comparison of photomicrograph documented taxa in this study (Appendix 2) with

304 Antoniades et al. (2008) for the Canadian Archipelago shows that $67 \%$ of the taxa observed in

305 FJL were present in both studies. This indicates a circumpolar distribution, along with some local 
306 species selectivity due to microhabitats and regions. In an earlier study, Foged (1981)

307 demonstrated that many more species are present in Arctic microhabitats, but often not recorded

308 due to their rare distributions. Interestingly, a small araphid species flock representing

309 Staurosirella, Staurosira, and Pseudostaurosira, was scarce in FJL, with only S. pinnata

310 abundant and characteristic of pond samples in cluster 2. This was also observed in Svalbard

311 (Pinseel et al. submitted). The Staurosirella, Staurosira, and Pseudostaurosira flocks typically

312 dominate hard substrate habitats in low productivity ponds and lakes across the Canadian and

313 western Russian Arctic (e.g. Metzeltin \& Witkowski 1996; Laing et al. 1999; Michelutti et al.

314 2003; Bouchard et al. 2004; Paull et al. 2008). In our study of the twenty most abundant taxa,

315 Nitzschia and Psammothidium were the most common genera with no clear associations within

316 species flocks. These genera, along with Achnanthidium, are indicative of moss and sediment

317 microhabitats. Moss wetlands have a diverse flora with select genera like Luticola, Humidophila,

318 and Eunotia having unique compositions (Douglas \& Smol 1995; Van De Vijver et al. 2003).

319 Luticola taxa observed from FJL were similar to the Novaya Zemlya Archipelago (Lange-

320 Bertalot \& Genkal 1999), while different from the Canadian Archipelago (Antoniades et al.

321 2008). Some common Arctic stream species, such as Hannaea arcus, occurred in low

322 abundance at FJL, which could be related to the absence of specific habitat requirements such as

323 high current velocity (Antoniades \& Douglas 2002). Likewise, taxa from the genera

324 Humidophila and Placoneis appeared to be species rich in FJL, which has also been observed in

325 Svalbard (Pinseel et al. submitted). In locations with more productive freshwater habitats, taxa

326 from the family Cymbellaceae (Cymbella, Cymbopleura, and Encyonema) are noted to be

327 abundant, with greater species richness, and widely distributed across microhabitats (Douglas \&

328 Smol 1995; Michelutti et al. 2003). Except for C. gandrupii, currently recognized circumpolar 
329 taxa do not dominate FJL assemblages, although species richness is clearly linked to circumpolar

330 and regionally endemic taxa (Fig. 2).

331 Geographic dispersal, especially with respect to a potential circumpolar flora, requires

332 mechanisms that are inherently controlled by climate. Freshwater organisms such as diatoms

333 could be dispersed by air as well as organisms such as birds, fishes, or mammals (Kristiansen

334 1996). Interestingly, Nansen (1897) documented a similarity in diatoms and microbes in melt

335 water pools from the Bering Strait and Greenland, and along with other observations, proposed

336 that drifting ice could pass across the North Pole. Cleve (1898) was the first to suggest a

337 potential circumpolar distribution of diatom species. Arctic drift ice has preferential pathways

338 throughout the Arctic region and has been found to transport viable freshwater algae such as

339 diatoms (Cleve 1898; Abelmann 1992; Pfirman et al. 1997). Therefore, drifting ice could be an

340 important mechanism for dispersal, hence the recognition of a circumpolar flora. Additionally,

341 airborne diatoms could also reach different Arctic regions. For example, dust storms routinely

342 transport particulates from northern Asia to western North America (Chin et al. 2007). In this

343 regards, population genetic studies of diatoms across the Arctic can assist in answering questions

344 of biogeographic distribution (Hamilton et al. 2015). Specifically, population genetics may help

345 identify potential vectors of migration like drifting ice trajectories, atmospheric wind patterns,

346 and bird migration pathways.

347 Consequently, the concept of circumpolar diatom species is applicable to a broader region

348 including northern boreal regions from the Palearctic and Nearctic areas. For instance, the

349 presence of Boreozonacola hustedtii recently described from a Mongolian peat-bog (Kulikovskiy

350 et al. 2010), has been found in Siberia (Lange-Bertalot \& Genkal 1999), Lapland (Lange-Bertalot 
351 \& Metzeltin 1996), Canada (Zimmermann et al. 2010), the Rocky Mountains USA (Bahls 2010), 352 and in FJL.

\section{Future scenarios of diversity}

354 Franz Josef Land Archipelago is a "zakaznik” Russian protected area (nature refuge

355

356

357

358

359 corresponding to IUCN IV). As in Antarctica, climate change and an increasing human footprint are the two main threats for conservation in FJL (Chown et al. 2012). However, due to the poor knowledge of diatom distribution and ecology, it is difficult to predict future changes in productivity and diversity. Current predictions are theoretical using knowledge from other regions and ecological theory.

Arctic biodiversity has been exposed to strong selection mechanisms in harsh and fluctuating environments (glaciation/deglaciation periods) for millennia. However, at present we consider rapid climate change as the main factor impacting biodiversity in polar ecosystems (Millennium Ecosystem Assessment 2005). In addition to climate change, increasing human activity (e.g., shipping, mining, fishing, tourism) in the Arctic are new stressors that need to be assessed, as well as other stressors such as global atmospheric pollution and species invasions, which could push the Arctic ecosystems to unknown scenarios (Larsen et al. 2014). All these threats imply rapid changes in the local environments (habitat change) and associated environment connectivity (dispersal mechanisms); both factors will modify the FJL freshwater ecosystems and communities.

Rapid environmental change can lead to a reduction in species richness and diversity (extinction event), which is often followed by a transition to novel communities dominated by generalist species with broader niches (Blois et al. 2013). This scenario represents a possible negative 
373 impact on specialized circumpolar taxa, with lower densities in FJL and other Arctic regions.

374 There is a decreasing diversity gradient from the equator to the poles, although it is weaker and

375 patchier for freshwater compared to terrestrial ecosystems (Hillebrand 2004). Paleolimnological

376 records across the Arctic region indicate that recent climate warming has driven diatom

377 compositional changes with an increase in local diatom richness. These changes have been

378 related to an increase in the length of the growing season (ice-free period), which increase habitat

379 availability and the structural complexity of diatom communities (e.g. development of complex

380 of periphytic communities) (Smol et al. 2005; Lim et al. 2008). An increase in air temperature,

381 and consequently an increase in the length of the ice-free season (growing period) would

382 facilitate the establishment of species from warmer regions (i.e. Lapland, low tundra in the

383 Canadian Arctic), as has been observed in other ecosystems (Dornelas et al. 2014). The

384 introduction of species would be accelerated by the expected increase in connectivity among

385 Arctic regions due to an increase in the human footprint. In addition, an increase in temporal

386 climate variability (seasonal and inter-annual) could promote species coexistence by reducing

387 competitive exclusion through fluctuation-dependent mechanisms such as storage effect and

388 relative nonlinearities of competition (Chesson 2000). Our data show that sites with higher

389 diversity are characterized by the presence of slightly acidophilic and aerophilic species (cluster

390 2), which indicate fluctuating environmental conditions.

391 However, to sustain local species diversity, the total surface area of available habitat must be

392 maintained. Despite the lower surface area-taxa richness relationship in high latitude regions and

393 in freshwater ecosystems, it is higher for islands (Drakare et al. 2006). Hence, in the short-term,

394 FJL will increase aquatic freshwater habitats due to melting ice as reported from other similar

395 arctic regions (e.g. Pinseel et al. submitted). In the long-term, the expected decrease of water 
396 bodies in the Arctic related to climate warming such as changes in the permafrost (i.e. loss of

397 thermokarst lakes) (Larsen et al. 2014) and a reduction of ice would lower habitat availability,

398 despite the observed pole-ward transport of moisture (Zhang et al. 2012). Consequently, we

399 would expect a short term increase in diversity due to a warmer climate, followed by a decrease

400 due to habitat loss.

401 At the global scale there are predicted increases in rates of extinction, particularly in the polar 402 regions (Millennium Ecosystem Assessment 2005). However, there is evidence that biodiversity 403 will remain constant or even increase over time (Vellend et al. 2013; Dornelas et al. 2014),

404 including human impacted areas and isolated oceanic islands (Sax et al. 2002). This apparent 405 contradiction (species loss versus gain) is due to different scales of study and measures of 406 diversity, which need to be taken into account when considering biodiversity patterns (McGill et 407 al. 2015). For instance, an increasing trend in local $\alpha$-diversity could parallel a decreasing trend 408 in global $\beta$-diversity (Sax \& Gaines 2003; Dornelas et al. 2014; Magurran et al. 2015).

409 One of the main factors determining $\beta$-diversity is regional connectivity and habitat

410 heterogeneity. The general expected increase in human footprint related activities across

411 circumpolar regions (e.g. tourism, polar transport, fishing, and natural resource extraction) would

412 increase the homogenization of communities across the Arctic, therefore reducing $\beta$-diversity.

413 Conversely, if drifting sea-ice has been enhancing FJL diatoms $\alpha$-diversity by facilitating

414 propagule dispersion, then a reduction in sea-ice would increase $\beta$-diversity. This change in

415 diversity could be offset by an increase in human visitation. Ice-floe trajectories over FJL 416 archipelago show two main sources: one from the $\mathrm{Ob}$ and Yenisei rivers through the Kara Sea, 417 and the other from the Lena River and New Siberian Islands (Novosibirskiye Ostrova 418 Archipelago) through the Láptev Sea (Pfirman et al. 1997). FJL diatoms suggest connections 
419 with these northern Siberia areas. The continuous arrival of freshwater diatoms from northern

420 Siberia could also stabilize populations of rare diatom species (low abundance) species, which

421 would otherwise become extinct in a harsh and fluctuating environment.

422 In the short term, the $\alpha$-diversity of FJL diatoms is expected to increase with climate warming in

423 association with an increase in human activities. In contrast, $\beta$-diversity (circumpolar) is

424 expected to decrease due to an increase in circumpolar connectivity resulting from stressors

425 related to an increase in anthropogenic activities. However, in the longer-term, an expected loss

426 of freshwater bodies and habitat diversity could reduce diatom populations and increase

427 competitive exclusions and therefore local species extinctions (decreasing $\alpha$-diversity; Fig. 6).

428 This process would be worse for rare species, which are mainly of circumpolar distribution or

429 regionally distributed. We could argue that Arctic species have adapted to past climate

430 fluctuations and will be able to persist. However, the human footprint will compound the impact

431 of isolation due to less sea-ice (extension and duration), which has occurred in past warmer

432 periods, consequently producing a net loss in $\beta$-diversity (Fig. 6). Therefore, local $\alpha$-diversity

433 could not be replenished as fast as in previous periods with the return of a new colder climate

434 period in association with a parallel increase in connectivity across the Arctic Ocean.

435 Our discussion is founded on the novelty of the recent warming (habitat change), which parallels

436 an increase in Arctic human activity (dispersal facilitation). However changes in other

437 environmental and dispersal factors such as bird migration pathways, and atmospheric and ocean

438 circulation modes could also affect the distribution of circumpolar diatoms. Furthermore, the

439 sensitivity and adaptability of diatoms to environmental change are also dependent on

440 endogenous factors (e.g. genetic diversity, phenotypic plasticity, species traits, populations

441 density, fitness, dispersal ability, persistence, etc.), which are likely to modulate a disparity in 
442 diatom responses to external threats and consequently their vulnerability and future distribution

443 (Dawson et al. 2011).

444 Finally, the low frequency of small araphid species flocks such as Staurosirella, Staurosira, and

445 Pseudostaurosira, also observed in Svalbard (Pinseel et al. submitted), has interesting

446 biogeographic implications. A better distributional record of these taxa across the circumpolar

447 region is required including the need to explore more freshwater habitats in the FJL Archipelago,

448 such as hard substrate habitats, ponds, and stream that are largely influenced by sea birds

449 colonies, as well as other factors, to characterize the complete diatom diversity of this isolated

450 and northern archipelago.

451 To conclude, there is an urgent need to explore the Arctic to understand, predict, and mitigate

452 future environmental change scenarios to preserve this unique ecosystem. In this regard,

453 monitoring programs and/or paleolimnological approaches using diatoms as environmental

454 indicators could be used as early warnings of environmental changes.

455

456 Acknowledgements

457 We thank to the Russian Arctic National Park and the Ministry of Natural Resources and the

458 Environment of the Russian Federation for their support and providing permits for the

459 expedition. Thanks to the Russian Geographical Society, the Russian Academy of Sciences,

460 Victor Boyarsky, and Sergey Kislyak, for their support and to National Geographic "Pristine

461 Seas Expedition FJL 2013”.

462 
463

464

465

466

467

468

469

470

471

472

473

474

475

476

477

478

479

480

481

482

483

484

485

486

487

488

489

490

491

492

493

494

495

496

497

498

499

500

501

502

503

504

505

506

507

508

509

\section{References}

Abelmann A. 1992. Diatoms assemblages in Arctic sea ice- Indicator for ice drift pathways. Deep-Sea Research Part a-Oceanographic Research Papers 39:S525-S538.

Adler PB, White EP, Lauenroth WK, Kaufman DM, Rassweiler A, and Rusak JA. 2005. Evidence for a general species-time-area relationship. Ecology 86:2032-2039.

AMAP. 2015. Arctic Monitoring and Assesment Programme. Available at http://www.amap.no/.

Antoniades D, and Douglas MSV. 2002. Characterization of high arctic stream diatom assemblages from Cornwallis Island, Nunavut, Canada. Canadian Journal of Botany 80:50-58.

Antoniades D, Douglas MSV, and Smol JP. 2004. Diatom species-environment relationships and inference models from Isachsen, Ellef Ringnes Island, Canadian High Arctic. Hydrobiologia 529:118.

Antoniades D, Douglas MSV, and Smol JP. 2005. Benthic diatom autoecology and inference model development from the Canadian Arctic Archipelago. Journal of Phycology 41:30-45.

Antoniades D, Hamilton PB, Douglas MSV, and Smol JP. 2008. Diatoms of North America : the freshwater floras of Prince Patrick, Ellef Ringnes and northern Ellesmere Islands from the Canadian Arctic Archipelago. Ruggell [Liechtenstein]; Königstein, Germany: A.R.G. Gantner ; Distributed by Koeltz Scientific Books.

Bahls L. 2010. Boreozonacola hustedtii. Available at http://westerndiatoms.colorado.edu/taxa/species/boreozonacola_hustedtii.

Battarbee RW, Jones VJ, Flower RJ, Cameron NG, Bennion H, Carvalho L, and Juggins S. 2001. Diatoms. In: Smol JP, Birks HJB, and Last WM, eds. Tracking Environmental Change Using Lake Sediments Volume 3: Terrestrial, Algal, and Siliceous Indicators Dordrecht: Kluwer Academic Publishers, 155-202.

Blois JL, Zarnetske PL, Fitzpatrick MC, and Finnegan S. 2013. Climate Change and the Past, Present, and Future of Biotic Interactions. Science 341:499-503.

Bouchard G, Gajewski K, and Hamilton PB. 2004. Freshwater diatom biogeography in the Canadian Arctic Archipelago. Journal of Biogeography 31:1955-1973.

Chernova NV, Friedlander AM, Turchik A, and Sala E. 2014. Franz Josef Land: extreme northern outpost for Arctic fishes. PeerJ 2:e692.

Chesson P. 2000. Mechanism of Maintenance of Species Diversity. Annual Review of Ecology and Systematics 31:343-366.

Chetelat J, Poulain AJ, Amyot M, Cloutier L, and Hintelmann H. 2014. Ecological determinants of methylmercury bioaccumulation in benthic invertebrates of polar desert lakes. Polar Biology 37:1785-1796.

Chin M, Diehl T, Ginoux P, and Malm W. 2007. Intercontinental transport of pollution and dust aerosols: implications for regional air quality. Atmos Chem Phys 7:5501-5517.

Chown SL, Lee JE, Hughes KA, Barnes J, Barrett PJ, Bergstrom DM, Convey P, Cowan DA, Crosbie K, Dyer G, Frenot $Y$, Grant SM, Herr D, Kennicutt li MC, Lamers M, Murray A, Possingham HP, Reid K, Riddle MJ, Ryan PG, Sanson L, Shaw JD, Sparrow MD, Summerhayes C, Terauds A, and Wall DH. 2012. Challenges to the future conservation of the antarctic. Science 337:158-159.

Cleve PT. 1898. Diatoms from Franz Josef Land collected by the Harmsworth-Jackson expedition. Stockholm.

Dawson TP, Jackson ST, House JI, Prentice IC, and Mace GM. 2011. Beyond Predictions: Biodiversity Conservation in a Changing Climate. Science 332:53-58.

De Cáceres M, and Legendre P. 2009. Associations between species and groups of sites: indices and statistical inference. Ecology 90:3566-3574.

Dibner VD, and Fursenko RV. 1998. Geology of Franz Josef Land. Oslo: Norsk polarinstitutt. 
510

511

512

513

514

515

516

517

518

519

520

521

522

523

524

525

526

527

528

529

530

531

532

533

534

535

536

537

538

539

540

541

542

543

544

545

546

547

548

549

550

551

552

553

554

555
Dornelas M, Gotelli NJ, McGill B, Shimadzu H, Moyes F, Sievers C, and Magurran AE. 2014. Assemblage Time Series Reveal Biodiversity Change but Not Systematic Loss. Science 344:296-299.

Douglas MSV, and Smol JP. 1995. Periphytic diatom assemblages from high artic ponds. Journal of Phycology 31:60-69.

Drakare S, Lennon JJ, and Hillebrand H. 2006. The imprint of the geographical, evolutionary and ecological context on species-area relationships. Ecology Letters 9:215-227.

Engstrom DR, Fritz SC, Almendinger JE, and Juggins S. 2000. Chemical and biological trends during lake evolution in recently deglaciated terrain. Nature 408:161-166.

Foged N. 1953. Diatoms from west Greenland Meddelelser om Gronland 147:1-86.

Foged N. 1955. Diatoms from Peary Land, North Greenland Meddelelser om Gronland 128/7:1-90.

Foged N. 1958. The diatoms in the basalt area and adjoining areas of Archean rock in West Greenland. Meddelelser om Gronland 156:1-146.

Foged N. 1964. Freshwater diatoms from Spitsbergen. Tromso Mus Skr 11:1-204.

Foged N. 1973. Diatoms from Southwest Greenland. Meddelelser om Gronland 194:1-84.

Foged N. 1974. Freshwater Diatoms in Iceland. J. Cramer, 1-192.

Foged N. 1977. The diatoms in four postglacial deposits at Godthabsfjord, West Greenland. Meddelelser om Gronland 199:1-64.

Foged N. 1981. Diatoms in Alaska. J. Cramer, 1-318.

Førland EJ, Benestad R, Hanssen-Bauer I, Haugen JE, and Skaugen TE. 2011. Temperature and Precipitation Development at Svalbard 1900-2100. Advances in Meteorology Article ID 893790:14 pages.

Gajewski K, Hamilton PB, and McNeely R. 1997. A high resolution proxy-climate record from an arctic lake with annually-laminated sediments on Devon Island, Nunavut, Canada. Journal of Paleolimnology 17:215-225.

Grunow A. 1884. Die Diatomeen von Franz Josefs-Land. Wien: Kaiserlich-Königlichen Hof- und Staatsdruckerei.

Hamilton PB, Lefebvre K, and Bull R. 2015. Single cell PCR amplification of diatoms using fresh and preserved samples. Frontiers in microbiology 6.

Hillebrand H. 2004. On the generality of the latitudinal diversity gradient. American Naturalist 163:192211.

Hughes AR, Byrnes JE, Kimbro DL, and Stachowicz JJ. 2007. Reciprocal relationships and potential feedbacks between biodiversity and disturbance. Ecology Letters 10:849-864.

Jones VJ, and Birks HJB. 2004. Lake-sediment records of recent environmental change on Svalbard: results of diatom analysis. Journal of Paleolimnology 31:445-466.

Jost L. 2007. Partitioning diversity into independent alpha and beta components. Ecology 88:2427-2439.

Jost L. 2010. The relation between evenness and diversity. Diversity 2:207-232.

Krammer K. 2000. The genus Pinnularia. Ruggell: A.R.G. Gantner Verlag.

Krammer K. 2002. Cymbella. Ruggell; Königstein: A.R.G. Gantner Verlag.

Krammer K. 2003. Cymbopleura, Delicata, Navicymbula, Gomphocymbellopsis, Afrocymbella. Ruggell; Königstein/Germany: A.R.G. Gantner Verlag.

Kristiansen J. 1996. Dispersal of freshwater algae- a review. Hydrobiologia 336:151-157.

Kulikovskiy MS, Lange-Bertalot H, Witkowski A, Dorofeyuk N, and Genkal S. 2010. Diatom assemblages from Sphagnum bogs of the world. Stuttgart, Germany: J. Cramer.

Laing TE, Pienitz R, and Smol JP. 1999. Freshwater diatom assemblages from 23 lakes located near Norilsk, Siberia: A comparison with assemblages from other circumpolar treeline regions. Diatom Research 14:285-305. 
556

557

558

559

560

561

562

563

564

565

566

567

568

569

570

571

572

573

574

575

576

577

578

579

580

581

582

583

584

585

586

587

588

589

590

591

592

593

594

595

596

597

598

599

600

601

602

Lange-Bertalot H. 2001a. Diatoms of Europe: Diatoms of the European inland waters and comparable habitats. Vol. 2, Navicula sensu stricto 10 Genera separated from Navicula sensu lato Frustulia. Ruggell; Königstein: A.R.G. Gantner ; Koeltz Scientific Books (distributor).

Lange-Bertalot H. 2001b. Navicula sensu stricto. 10 Genera separated from Navicula sensu lato. Frustulia. Ruggell: A.R.G. Ganter Verlag.

Lange-Bertalot H, Bak M, and Witkowski A. 2011. Eunotia and some related Genera. Ruggell: A.R.G. Gantner Verlag

Lange-Bertalot H, and Genkal SI. 1999. Diatoms from Siberia. Diatomeen aus Sibirien. I, Inseln im Arktischen Ozean (Yugorsky Shar Strait). Vaduz [Liechtenstein]; Königstein, Germany: A.R.G. Gantner ; Distributed by Koeltz Scientific Books.

Lange-Bertalot H, and Metzeltin D. 1996. Indicators of oligotrophy - 800 taxa representative of three ecologically distinct lake types, Carbonate buffered - Oligodystrophic - Weakly buffered soft water. Königstein, Germany: Koeltz Scientific.

Larsen JN, Anisimov OA, Constable A, Hollowed AB, Maynard N, Prestrud P, T.D. Prowse TD, and Stone JMR. 2014. Polar regions. In: Barros VR, Field CB, Dokken DJ, Mastrandrea MD, Mach KJ, Bilir TE, Chatterjee M, Ebi KL, Estrada YO, Genova RC, Girma B, Kissel ES, Levy AN, MacCracken S, Mastrandrea PR, and White LL, eds. Climate Change 2014: Impacts, Adaptation, and vulnerability Part B: Regional Aspects Contribution of working Group II to the Fifth Assessment Report of the Intergovernmental Panel on Climate Change. Cambridge Cambridge University Press, 1567-1612.

Legendre P, and Legendre L. 1998. Numerical Ecology. Amsterdam: Elsevier.

Levkov Z. 2013. Amphora sensu lato. Königstein: Koeltz Scientific Books.

Lim D, Smol J, and Douglas M. 2008. Recent environmental changes on Banks Island (N.W.T., Canadian Arctic) quantified using fossil diatom assemblages. Journal of Paleolimnology 40:385-398.

Magurran AE, Dornelas M, Moyes F, Gotelli NJ, and McGill B. 2015. Rapid biotic homogenization of marine fish assemblages. Nat Commun 6:8405.

McGill BJ, Dornelas M, Gotelli NJ, and Magurran AE. 2015. Fifteen forms of biodiversity trend in the Anthropocene. Trends in Ecology \& Evolution 30:104-113.

Metzeltin D, and Witkowski A. 1996. Diatomeen der Bären-Insel. Königstein, Germany: Koeltz Scientific. Michelutti N, Holtham AJ, Douglas MSV, and Smol JP. 2003. Periphytic diatom assemblages from ultraoligotrophic and UV transparent lakes and ponds on Victoria Island and comparisons with other diatom surveys in the Canadian Arctic. Journal of Phycology 39:465-480.

Millennium Ecosystem Assessment. 2005. Millennium Ecosystem Assessment. Ecosystems and Human Well-being: Biodiversity Synthesis. Washington, DC.

Milner AM, Fastie CL, Chapin FS, Engstrom DR, and Sharman LC. 2007. Interactions and linkages among ecosystems during landscape evolution. Bioscience 57:237-247.

Nansen F. 1897. Farthest North. New York: Harper \& Brothers.

Paull TM, Hamilton PB, Gajewski K, and LeBlanc M. 2008. Numerical analysis of small Arctic diatoms (Bacillariophyceae) representing the Staurosira and Staurosirella species complexes. Phycologia 47:213-224.

Pfirman SL, Colony R, Nurnberg D, Eicken H, and Rigor I. 1997. Reconstructing the origin and trajectory of drifting Arctic sea ice. Journal of Geophysical Research-Oceans 102:12575-12586.

Pinseel E, van de Vijver B, Kavan J, Verleyen E, and Kopalova K. submitted. Diversity, ecology and community structure of the freshwater littoral diatom flora from Petuniabukta (Spitsbergen). Polar Biology.

Pla-Rabes S, Toro M, Van De Vijver B, Rochera C, Villaescusa JA, Camacho A, and Quesada A. 2013. Stability and endemicity of benthic diatom assemblages from different substrates in a maritime 
603

604

605

606

607

608

609

610

611

612

613

614

615

616

617

618

619

620

621

622

623

624

625

626

627

628

629

630

631

632

633

634

635

636

637

638

639

640

641

642

643

644

645

646

647

648

stream on Byers Peninsula, Livingston Island, Antarctica: the role of climate variability. Antarctic Science 25:254-269.

Sax DF, and Gaines SD. 2003. Species diversity: from global decreases to local increases. Trends in Ecology \& Evolution 18:561-566.

Sax DF, Gaines SD, and Brown JH. 2002. Species Invasions Exceed Extinctions on Islands Worldwide: A Comparative Study of Plants and Birds. The American Naturalist 160:766-783.

Shirshov P. 1935. Ecological and geographical essay of freshwater diatoms of Novaya Zemlya and FranzJosef Land. [In Russian]. Transactions of Arctic Institute Leningrad 14:73-162.

Smol JP, Wolfe AP, Birks HJB, Douglas MSV, Jones VJ, Korhola A, Pienitz R, Ruhland K, Sorvari S, Antoniades D, Brooks SJ, Fallu MA, Hughes M, Keatley BE, Laing TE, Michelutti N, Nazarova L, Nyman M, Paterson AM, Perren B, Quinlan R, Rautio M, Saulnier-Talbot E, Siitoneni S, Solovieva $\mathrm{N}$, and Weckstrom J. 2005. Climate-driven regime shifts in the biological communities of arctic lakes. Proceedings of the National Academy of Sciences of the United States of America 102:4397-4402.

Solheim A, E. M, and Heintz N. 1998. Geological Aspects of Franz Josef Land and the Nothmost Barents Sea. Oslo: Norks Polar Institute.

Stanish LF, Nemergut DR, and McKnight DM. 2011. Hydrologic processes influence diatom community composition in Dry Valley streams. Journal of the North American Benthological Society 30:10571073.

Stewart KA, Lamoureux SF, and Forbes AC. 2005. Hydrological controls on the diatom assemblage of a seasonal arctic river: Boothia Peninsula, Nunavut, Canada. Hydrobiologia 544:259-270.

ter Braak CJF, and Šmilauer P. 2012. Canoco Reference Manual and User's Guide: Software for Ordination (version 5.0). Wageningen: Microcomputer power, Itaca, www. canoco. com.

UNESCO. 2009. Climate change and Arctic sustainable development, scientific, social, cultural and educational challenges.

Van De Vijver B, Beyens L, and Lange-Bertalot H. 2004. The genus Stauroneis in the Arctic and (sub-) Antarctic regions.

Van De Vijver B, Van Kerckvoorde A, and Beyens L. 2003. Freshwater and terrestrial moss diatom assemblages of the Cambridge Bay area, Victoria Island (Nunavut, Canada). Nova Hedwigia 76:225-243.

Vellend M, Baeten L, Myers-Smith IH, Elmendorf SC, Beauséjour R, Brown CD, Frenne P, Verheyen K, and Wipf S. 2013. Global meta-analysis reveals no net change in local-scale plant biodiversity over time. Proceedings of the National Academy of Sciences 110:19456-19459.

Weckstrom J, and Korhola A. 2001. Patterns in the distribution, composition and diversity of diatom assemblages in relation to ecoclimatic factors in Arctic Lapland. Journal of Biogeography 28:3145.

Williamson CE, Dodds W, Kratz TK, and Palmer MA. 2008. Lakes and streams as sentinels of environmental change in terrestrial and atmospheric processes. Frontiers in Ecology and the Environment 6:247-254.

Zauer LM. 1963. Some data on diatoms of Hayes Island (Franz-Josef Land ). [In Russian]. . Vestnik of Leningrad State University Series Biology 4:27-37.

Zhang X, He J, Zhang J, Polyakov I, Gerdes R, Inoue J, and Wu P. 2012. Enhanced poleward moisture transport and amplified northern high-latitude wetting trend. Nature Climate Change 3:47-51.

Zimmermann C, Poulin M, and Pienitz R. 2010. Diatoms of North America : the Pliocene-Pleistocene freshwater flora of Bylot Island, Nunavut, Canadian high Arctic. Ruggell [Liechtenstein]; Königstein, Germany: A.R.G. Gantner ; Distributed by Koeltz Scientific Books. 


\begin{tabular}{|c|c|c|c|c|c|c|c|c|c|c|}
\hline Code & Locality & $\mathrm{NN}$ & $\mathrm{EE}$ & Habitat & Date & $\mathrm{S}$ & $\mathrm{ExpH}$ & Simpson & EF-1 & EF-2 \\
\hline$\overline{\text { FJ01 }}$ & $\begin{array}{l}\text { Cape Flora, } \\
\text { Northbrook Island }\end{array}$ & 79.9453 & 50.1295 & pond 1 & 5 August & 37 & 5.8 & 3.3 & 0.156 & 0.089 \\
\hline FJ02 & $\begin{array}{l}\text { Cape Flora, } \\
\text { Northbrook Island }\end{array}$ & 79.9453 & 50.1295 & pond 2 & 5 August & 30 & 10.3 & 6.7 & 0.345 & 0.224 \\
\hline FJ03 & $\begin{array}{l}\text { Cape Flora, } \\
\text { Northbrook Island }\end{array}$ & 79.9453 & 50.1295 & stream & 5 August & 9 & 1.9 & 1.5 & 0.212 & 0.165 \\
\hline FJ04 & $\begin{array}{l}\text { Cape Flora, } \\
\text { Northbrook Island }\end{array}$ & 79.9453 & 50.1295 & pond 3 & 5 August & 35 & 10.8 & 7.4 & 0.307 & 0.211 \\
\hline FJ05 & $\begin{array}{l}\text { Cape Flora, } \\
\text { Northbrook Island }\end{array}$ & 79.9453 & 50.1295 & pond 4 & 5 August & 34 & 12.4 & 8.4 & 0.365 & 0.248 \\
\hline FJ06 & $\begin{array}{l}\text { Tikhaya Bay, } \\
\text { Hooker island }\end{array}$ & 80.3362 & 52.7758 & pond 1 & 31 July & 64 & 26.8 & 14.1 & 0.418 & 0.220 \\
\hline FJ07 & $\begin{array}{l}\text { Tikhaya Bay, } \\
\text { Hooker island }\end{array}$ & 80.3362 & 52.7758 & pond 2 & 31 July & 40 & 9.4 & 5.6 & 0.234 & 0.139 \\
\hline FJ08 & Wilczeck Land & 80.6109 & 61.9859 & stream & 15 August & 18 & 8.7 & 7.0 & 0.483 & 0.388 \\
\hline FJ09 & Mabel Island & 80.0193 & 49.3579 & nearshore stream & 25 August & 31 & 5.7 & 3.3 & 0.183 & 0.105 \\
\hline FJ10 & Mabel Island & 80.0193 & 49.3579 & uphill stream & 25 August & 21 & 7.1 & 4.8 & 0.340 & 0.227 \\
\hline FJ11 & Nansen Island & 80.5502 & 54.1329 & glacier stream & 23 August & 36 & 13.3 & 8.7 & 0.369 & 0.243 \\
\hline FJ12 & Mabel Island & 80.0111 & 49.3791 & small lake 1 & 21 August & 36 & 12.1 & 6.8 & 0.337 & 0.189 \\
\hline FJ13 & Mabel Island & 80.0111 & 49.3791 & small lake 2 & 21 August & 36 & 13.5 & 8.4 & 0.376 & 0.234 \\
\hline FJ14 & Wilton Island & 80.5613 & 54.3557 & stream & 23 August & 64 & 25.2 & 15.0 & 0.393 & 0.234 \\
\hline FJ15 & $\begin{array}{l}\text { Cape Tegethoff, } \\
\text { Hall Island }\end{array}$ & 80.0926 & 58.0584 & nearshore pond & 11 August & 59 & 30.8 & 17.3 & 0.522 & 0.294 \\
\hline FJ16 & Kuhn Island & 81.1047 & 58.3721 & small stream & 9 August & 48 & 18.2 & 9.9 & 0.379 & 0.206 \\
\hline FJ17 & Alger Island & 80.3529 & 56.1413 & small stream 1 & 14 August & 36 & 9.4 & 5.2 & 0.261 & 0.144 \\
\hline FJ18 & Alger Island & 80.3820 & 55.7698 & small stream 2 & 14 August & 35 & 11.7 & 7.8 & 0.334 & 0.222 \\
\hline
\end{tabular}

650 Table 1 Sample localities, geographic coordinates, habitat type and sampling date. NN (latitude N.), EE (longitude E), S (species richness), ExpH (exponential of Shannon Entropy), Simpson (Simpson diversity index), EF-1 evenness of order 1 and EF-2 evenness 652 of order 2 (Jost, 2010). 


\section{Figure captions}

654 Figure 1 Diatoms samples localities in Franz Josef-Land Archipelago. Orange dots denote 655 stream samples, and green dots pond samples. Numbers are sample codes from table 1.

656 Figure 2. Dot plot of FJL diatom assemblages for all samples sites and diatoms with higher 657 abundance ( $>2 \%$ ). Species are sorted across PCO axis 2 scores ( $\mathrm{pH}$ gradient). Samples are 658 sorted across the PCO axis 1 (from ponds to streams). Sites in blue denotes stream habitat. 659 Symbol size indicates the relative abundance of each taxa for each site. Symbols colour indicates 660 Indval value for species in each K-means cluster. Symbol shape denotes species geographic 661 distribution.

662 Figure 3. Stream and pond (including lake) samples diversity metrics boxplots. Evenness-F1 and 663 Evenness-F2 are evenness factor of order 1 and of order 2 following Jost (2010).

664 Figure 4 PCO results. Ellipses are grouping results of K-means cluster analysis. Only the 25 665 species with highest correlation with one of the two main axes are showed. Numbers in red 666 denotes K-means cluster. Squares denote stream samples and circles ponds samples. Full species 667 names are reported in Appendix 1.

668 Figure 5 Diversity metrics boxplots for each k-means clusters (see plot legend). Evenness-F1 669 and Evenness-F2 are evenness factor of order 1 and of order 2 following Jost (2010).

670 Figure 6. Hypothetical models on how species richness changes on two different warming 671 scenarios. (A) Past warming periods; a.1) Increasing temperature would promote a rapid increase

672 in FJL $\alpha$-diversity, but a decrease of circumpolar $\beta$-diversity due to biotic homogenization across 673 the arctic. a.2) Shortly, the lower extension and duration of circumpolar sea-ice would increase 674 isolation among circumpolar regions, and different species would be locally selected. This 675 isolation would reverse the previous decreasing trend in $\beta$-diversity. a.3) However, later on, an 676 expected generalized loss of freshwater ecosystems and the consequent increase in local 677 competitive exclusion would reduce FJL $\alpha$-diversity. On the end of a warm period cycle (a.4) a 678 net increase on circumpolar diversity ( $\gamma$-diversity) would be expected by local speciation. (B) 679 Anthropocene warming scenario. Would be expected similar changes on $\alpha$-diversity, however, 680 the higher expected human frequentation would increase connectivity, which would cancel out 681 the positive effects of isolation on $\beta$-diversity. This expected homogenization of circumpolar 682 diatom flora due to higher connectivity and the expected habitat lost (climate warming) could 683 reduce the overall $\gamma$-diversity with a net loss of circumpolar species. 


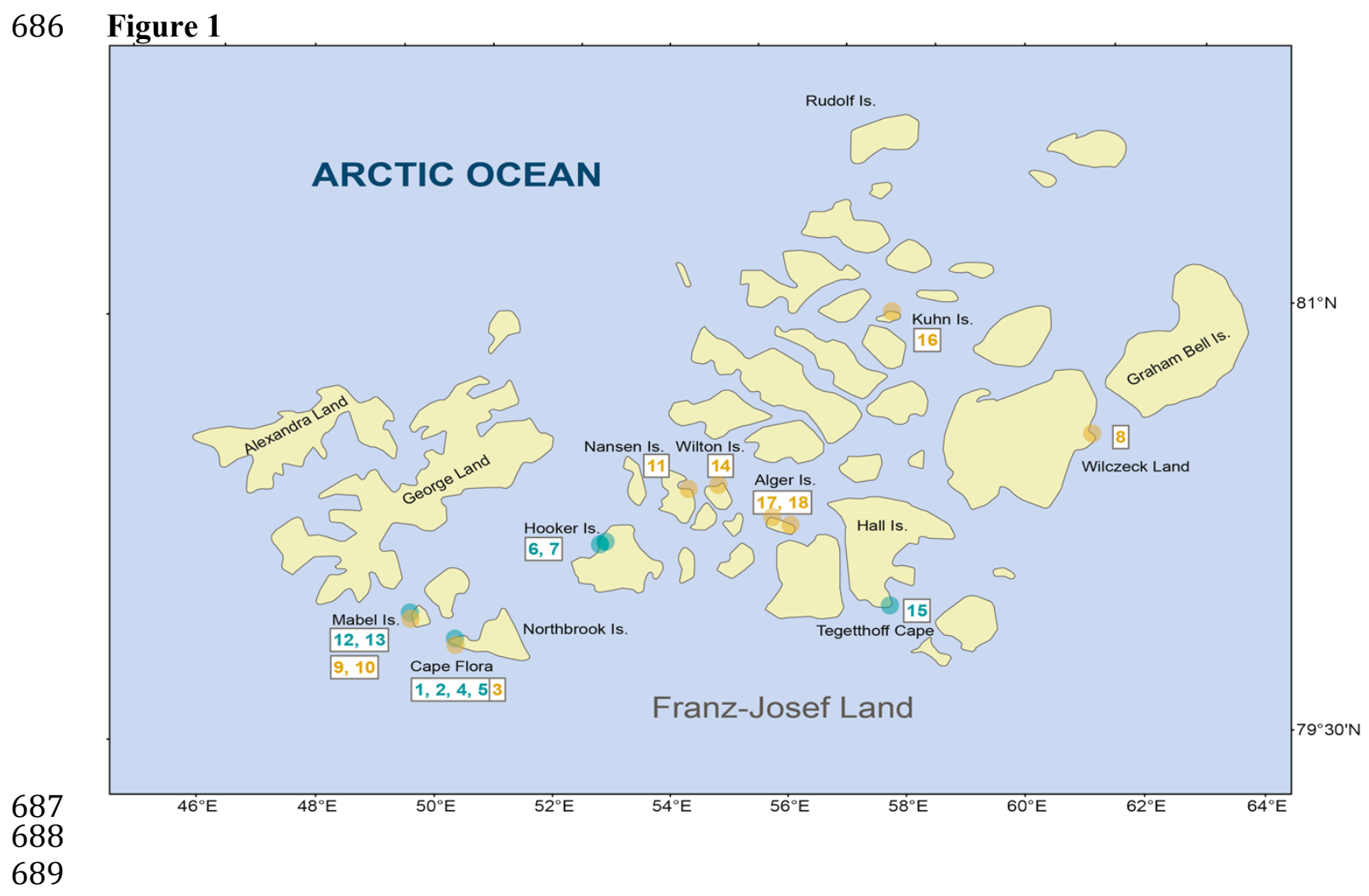


Figure 2

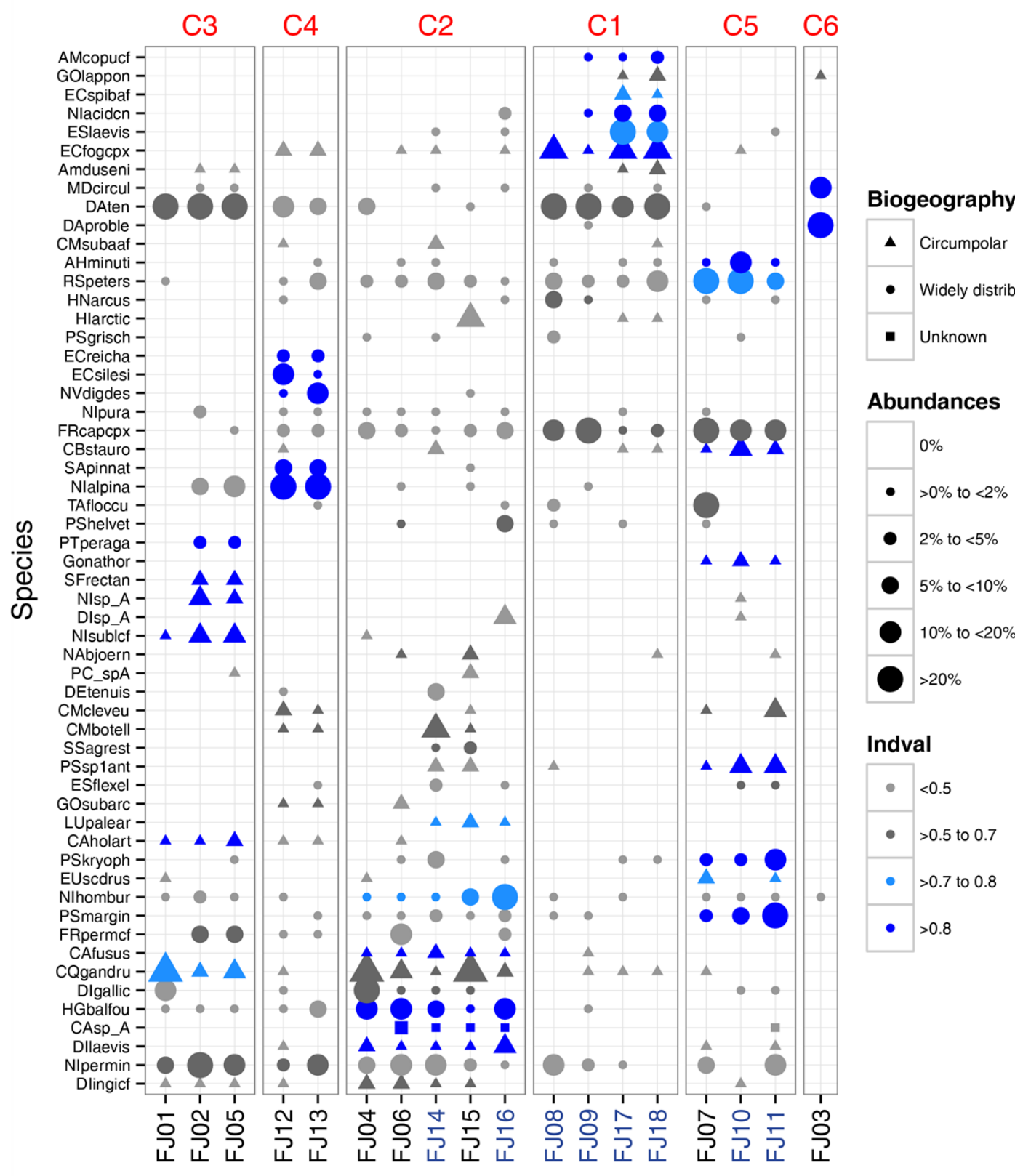

691 
693 Figure 3

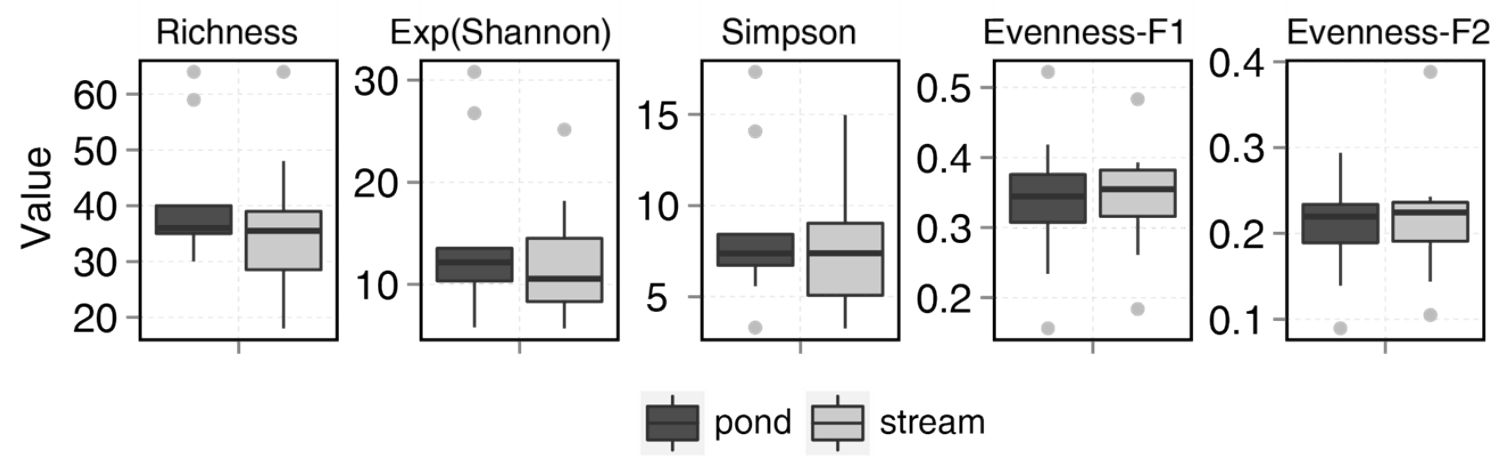

695 
696 Figure 4

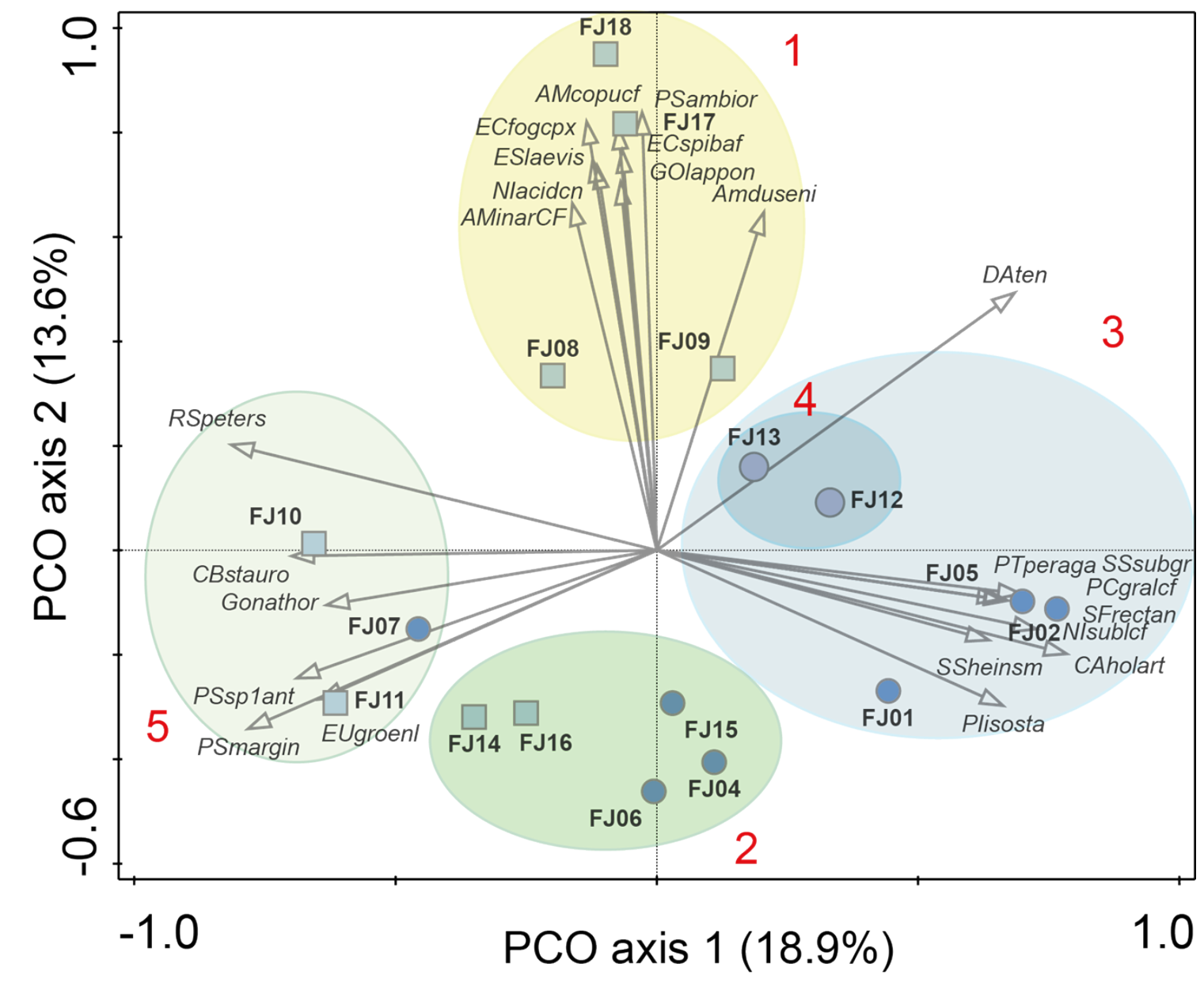

698 
$699 \quad$ Figure 5

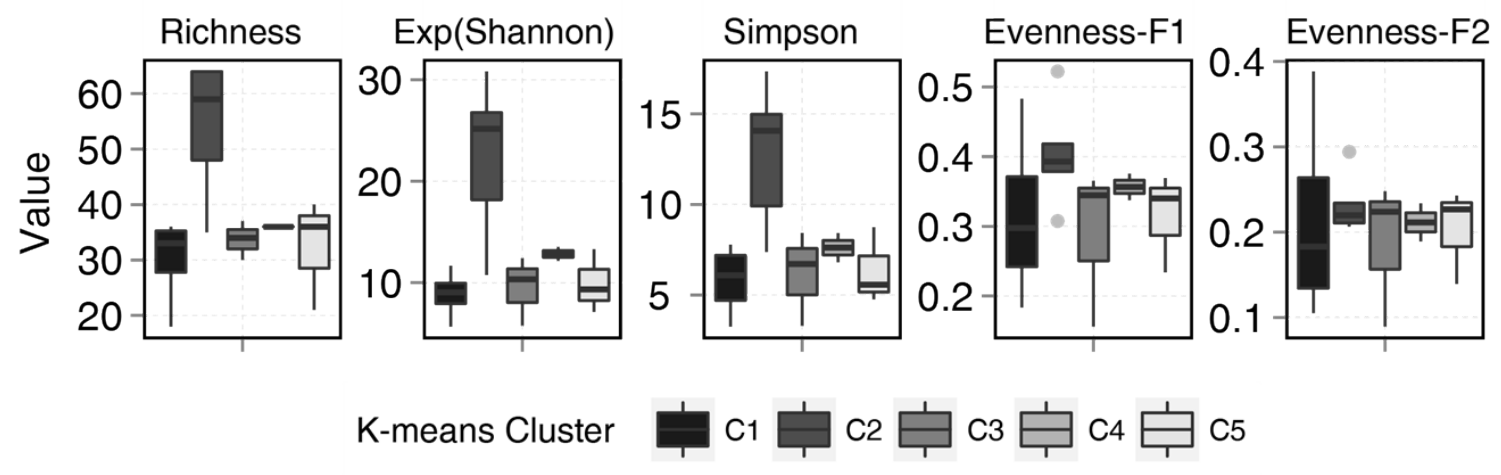

700

701 


\section{Figure 6}

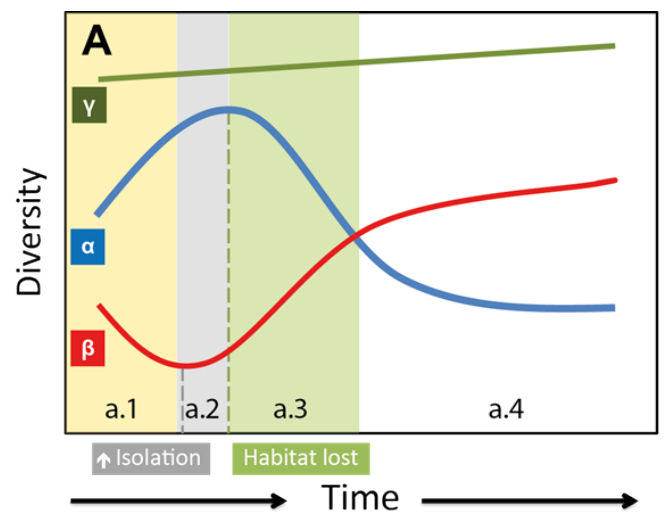

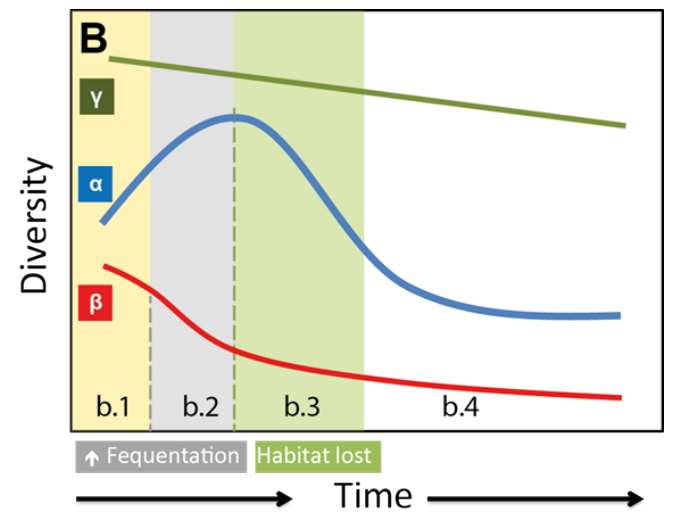

